\title{
The impact of the COVID-19 crisis on
}

\section{income distribution}

under different protection schemes: the case of Spain

GONZALO GÓMEZ BENGOECHEA, Ph.D.*

\section{Article ${ }^{* *}$}

JEL: H22, I3

https://doi.org/10.3326/pse.45.4.6

\footnotetext{
* The author would like to thank two anonymous referees for their useful comments and suggestions and the generous contributions by Lucía Blasco Guzmán, Siyu Quan and Valentina Vidal to this article. The previous version was published at: http://repec.tulane.edu/RePEc/ceq/ceq102.pdf.

${ }^{* *}$ Received: June 14, 2021

Accepted: August 21, 2021
}

Gonzalo GÓMEZ BENGOECHEA

Universidad Pontificia Comillas - ICADE, Alberto Aguilera, 23, Office OD-412, 28015 Madrid, Spain e-mail: gonzalo.gomez@comillas.edu ORCiD: 0000-0001-6377-9988 


\begin{abstract}
I use household survey data to microsimulate the impact of the COVID-19 crisis on income distribution in Spain. I estimate the cost of potential lockdowns under three different low-income public protection schemes. Results show that although the COVID-19 shock has reduced income for all deciles of the income distribution, the losses are not uniformly distributed. The worst economic effects of the pandemic are not on the poorest, but on individuals in the middle and wealthy groups of the ex-ante income distribution. Low-income benefits help to moderate income losses and to curb poverty and inequality at various levels. It might be necessary to raise taxes and to resort to expenditure reducing policies to maintain protection in the context of contraction and lower government revenues.
\end{abstract}

Keywords: fiscal incidence, inequality, poverty, social spending, COVID, Spain

\title{
1 INTRODUCTION
}

This paper examines the effects of low-income benefits on income distribution, inequality, and poverty in the context of a deep economic contraction. Worldwide, gross domestic product (GDP) experienced a 3.3\% fall in 2020. Advanced countries suffered a more profound recession than developing economies; GDP fell $4.7 \%$ for the former, and $2.2 \%$ for the latter. Within the group of advanced economies, Spain is the country with the deepest GDP fall: $10.8 \%$. Under these unprecedented circumstances, consequences on income, inequality and poverty must be explored, and policies designed to alleviate the social effects tested.

Spain is a country with a relatively generous welfare state. Social spending accounts for almost $25 \%$ of its GDP, well above the average for OECD countries (20.4\%). However, according to Ayala and Cantó (2020), in the last few years "inequality has shown some reluctance to fall, which indicates that it possesses a significant structural component". The two reasons behind this apparent paradox are the inefficient adjustment mechanisms of its labor market and the low redistribution capacity of fiscal interventions. These unique conditions are used to tackle the research question in this paper from the perspective of the Spanish case, but with the goal of drawing general lessons for advanced countries.

Figure $1^{1}$ shows the relationship between social expenditure and the Gini Index. The size of the dots corresponds with the percentage of the population living under the national poverty line ( $60 \%$ of median income). Data shows that Spain is a country with a relatively high social spending to GDP ratio and a relatively low redistribution capacity. The Gini Index for disposable income is 0.33 (OECD average is 0.31 ) and the poverty rate using the national poverty line is $14.2 \%$ (OECD average is $11.6 \%$ ).

\footnotetext{
${ }^{1}$ I have excluded Chile, Costa Rica, and Mexico for representation purposes. Their figures, as well as those of the other countries included in figure 1 , are shown in table A1 at the appendix section.
} 
I microsimulate the impact of different income contractions, mainly using data from Encuesta de Condiciones de Vida, (ECV). I complement ECV data with other surveys, like Encuesta de Presupuestos Familiares (EPF), and with information from fiscal-administrative sources. I construct all the income concepts contained in this article following Lustig (2013) approach.

\section{Figure 1}

Social spending as a percentage of GDP (vertical axis) and Gini Index (horizontal axis)

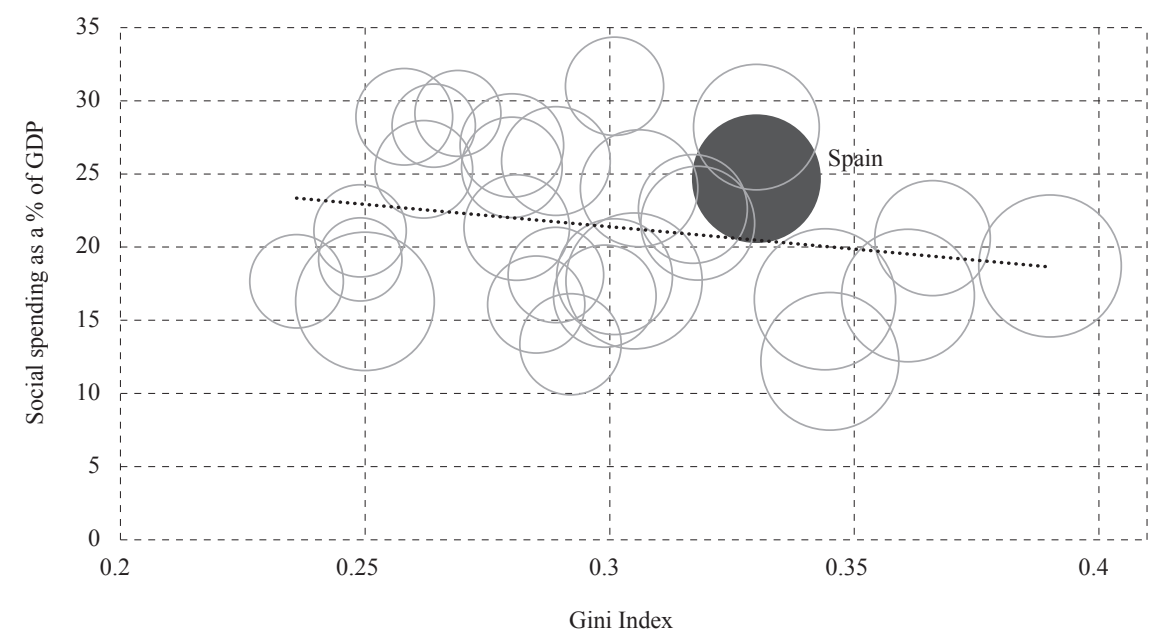

Note: OECD countries. 2019 or latest year with available data.

Source: OECD statistics.

Surveys like the ECV are produced almost globally on a yearly basis. Information provided by them offers a two-year delay from the moment in which the data were collected. This means that, to evaluate the impact of the COVID-19 crisis and of the different policies in effect, researchers and policymakers would need to wait until the moment in which data for the years 2020 and 2021 are published.

In this paper, I estimate different income contraction scenarios derived from lockdowns and their aftermaths in Spain. Spain is one of the countries most affected by the COVID pandemic (Pollán et al., 2020). Scenarios are simulated under three different low-income protection schemes. The first one acts as a benchmark since it does not include any specific low-income benefit. Throughout the article, I will refer to it as the NLIB (Not Low-Income Benefit) scheme. It considers all other transfers and subsidies in effect.

The second one includes a direct means-tested transfer from regional governments to households fulfilling each region's conditions (household size, health issues...). This protection scheme, also known in Spain as Renta Minima de Inserción (RMI), is a low-income benefit operative until the end of 2019. Finally, I 
simulate a national-wide means-tested program with the same conditions and regulation for all regions. This scheme is known as Ingreso Minimo Vital (IMV) (BOE, 2020). It was established as a replacement for RMI from 2020 onward. Details on both schemes are provided in section 3 .

The contribution of this article to the existing literature is twofold. First, I estimate the impact of the COVID crisis and its aftermath for the entire income distribution, and not only on aggregate or proportionally as is usual in the literature, using income and not spending data, as in Aspachs et al. (2020). Second, I provide an analysis of the protection provided by low-income benefits beyond the already existing articles on hypothetical Universal Basic Income (UBI) designs. My work also sheds light on the optimal design of low-income benefits under these extraordinary circumstances.

This article is structured as follows. In section 2, I present the theoretical framework and the literature review of fiscal incidence and of the COVID-19 impact on income distribution in Spain. Section 3 briefly summarizes the data and the methodology used to answer the research question. Section 4 shows the main results that I have obtained, and, in section 5, I discuss them and offer some policy recommendations. Finally, section 6 presents the conclusions of the article.

\section{THEORETICAL FRAMEWORK AND LITERATURE REVIEW}

Fiscal incidence analysis is rooted in the field of public finance. Literature on this topic analyzes and measures the distributional impact of a country's taxes and public spending. Tax incidence literature was initially focused on the US tax system. Musgrave et al. (1951), Musgrave (1959), Musgrave, Case and Leonard (1974), and Pechman (1985) were the main contributors to this research line providing the first estimations of the distributional effects of the US tax system. On the expenditure side, early studies on its incidence can be found in Keid (1954) and in the work of the Tax Foundation (1967).

Fiscal incidence analysis consists of allocating taxes and public spending to households or individuals in order to compare incomes before taxes and transfers with incomes after taxes, transfers, and subsidies (Förster and Whiteford, 2009; Immervoll and Richardson, 2011). This allocation process is done through different methodological strategies, although microsimulations from survey-based data are the most to be found in the literature (Bourguignon and Spadaro, 2006; Lustig, Pessino and Scott, 2014; del Valle Navas and de la Cruz, 2018).

Fiscal redistribution is the process by which the state collects revenues from individuals and households (primarily through taxes) and spends these revenues on benefits (for example, cash transfers, price subsidies, and in-kind benefits such as education and health) intended for specific individuals and households (Lustig, Pessino nad Scott, 2014). The state modifies post-fiscal income for households and individuals and alters inequality and poverty rates. 
As Lambert (1992) shows, "the redistributive effect of the net fiscal system is equal to the weighted sum of the redistributive effect of taxes and transfers, where the redistributive effect of the tax system is defined as the difference between inequality of post-tax and Market Income"; income distribution changes before and after public interventions.

Equation 1 summarizes this process.

$$
Y_{h}=I_{h}-\sum_{i} T_{i} S_{i h}+\sum_{j} B_{j} S_{j h}
$$

Where:

$Y_{h}=$ post-fiscal household income.

$I_{h}=$ pre-fiscal household income.

$T_{i}=$ total taxes levied on households.

$S_{i h}=$ share of tax $i$ paid by unit $h$.

$B_{j}=$ total transfers to households.

$S_{j h}=$ share of transfer $j$ received by unit $h$.

The so-called accounting approach dominates the literature on fiscal incidence. It considers what is paid and received without assessing the behavioral responses that taxes and public spending may trigger. This methodology starts from an income concept and depending on the fiscal intervention under study, allocates the proper amount of a tax or a transfer to each household or individual.

Given the nature of the research question addressed in this article, I will consider only the transfer element of equation 1. In particular, I will focus on the effect of low-income benefits on inequality and poverty rates during and in the aftermath of the COVID-19 crisis, as stated above.

All income concepts in this article have been produced using the methodology originally developed in Lustig (2018) and in Gómez-Bengoechea and Quan (2019), for the Spanish case. The analysis contained in this article is focused on gross income, which is the result of adding contributory pensions and direct transfers to market income minus the contributions to the social security for retirement pensions.

For the case of Spain, research estimates either the impact of COVID-19 on income, assuming that income losses are proportional across the entire distribution (Lustig and Pabon, 2020), or the particular case of a city or region, which is too narrow from the geographical point of view. An example of the former can be found in Clark, D'Ambrosio and Lepinteur (2020), where authors find that relative inequality increased, decreased, and grew again in a hump-shaped way in 2020 for France, Germany, Italy, Spain and Sweden. The latter can be found in Baena-Díez et al. (2020), who show that income reductions have affected the most deprived areas, for the city of Barcelona. 
Existing aggregate results for Spain are consistent with those found globally (Han, Meyer and Sullivan, 2020; Deaton, 2021). Both papers find that per capita incomes fell more in higher-income countries than in developing nations, even if the former had better protection schemes. The uneven impact of health crises in each region seems to be behind this counter-intuitive result.

An exception to those approaches can be found in Aspachs et al. (2020), which shows that public transfers and unemployment insurance schemes have been very effective at providing a safety net for the most affected segments of the population and at offsetting most of the increase in inequality. They show that in the absence of government intervention, spending inequality would have increased dramatically. In section 4, I will confirm those results and will separate the part of that safety net that can be attributed to low-income benefits.

From the income protection point of view, research on COVID's impact has been primarily focused hypothetical UBI strategies as a response to the crisis. That is the case for Johnson et al. (2020) and Johnson and Roberto (2020), which document how UBI may be suited to address these challenges as opposed to, or in conjunction with, other relief measures. For the pre-COVID period, there is a huge literature analyzing the role of both RMI and IMV in addressing income inequalities (Ayala et al., 2021; Aguilar-Hendrickson and Arriba González de Durana, 2020; Hernández, Picos and Riscado, 2020).

A low-income benefit is different from a universal basic income (UBI; beneficiaries of the former often face eligibility conditions, while the latter is granted for all citizens regardless of their wealth or family situation. The concept of a universal basic income (UBI), an unconditional flat-rate transfer paid to everyone, is rooted in the literature (Widerquist, 2013) and in the public debate. Policymakers (Horvarth and Wignaraja, 2020) support its use as a response to the magnitude of and the vulnerability generated by the COVID-19 crisis.

As has been already mentioned, this article contributes to the existing literature by providing income contraction results for the entire distribution and not only from a proportional or aggregate perspective. Furthermore, I provide an analysis of lowincome benefits that goes beyond the already existing UBI analyses and suggest some policy alternatives that could be explored to enhance current protection mechanisms.

\section{DATA AND METHODOLOGY}

I use microdata from the ECV Survey (2018) to build the main income concepts necessary to estimate the impact of the COVID-19 crisis on poverty and inequality. ECV is an income-based survey. It gathers information from almost 35,000 individuals and 13,000 households and offers data both nationally and regionally. It does not include consumption-related questions. Regarding household data, it offers information on the composition, income, social exclusion and material needs of the unit, as well as of the current state of the dwelling place. With respect 
to individuals, ECV contains information on education, health, labor conditions, income and material needs.

Microsimulations allow us to relax the equal loss assumption for the entire population often found in the literature. I use techniques analogous to non-anonymous growth incidence curves (Bourguignon, 2011) to describe income losses across the ex-ante income distribution and to incorporate distributional changes into the analysis.

I use gross income per capita as the benchmark income indicator (Lustig et al., 2020). Gross income is obtained as the aggregate of labor income, capital income, other household transfers, contributory pensions and direct public transfers. Direct public transfers include unemployment benefits, non-contributory pensions, national and regional family-related transfers, and the low-income benefit: RMI or IMV; alternatively. I update gross incomes for Spain using the growth rate of per capita GDP for 2019 multiplied by a so-called "pass through" of 0.85 . Ravallion (2003) and Lakner et al. (2019) recommend the use of this pass through to convert GDP changes into household disposable incomes variations.

Income losses are obtained by simulating potential impacts at the household level. I first identify individuals whose income is at risk because they work in sectors in which lockdowns have severely reduced activity. Second, I aggregate at-risk income to the household level and then simulate actual loses using a range of two parameters: the share of households with at-risk income that actually lose income, and the share of income lost for them. Both parameters vary from zero to one hundred percent.

The incomes of individuals are considered to be safe or at risk depending on the economic sector in which they work. I assume that income derived from work in sectors that are "essential" are not at risk. I use the International Labor Organization (ILO) definition of essential sectors (public services, health care and social services).

Following these criteria, I consider an economic sector to be at-risk if the aggregate variation of compensations paid to individuals fell more than the aggregate for all sectors (14.35\%) between March and April 2020, when the lockdown was more strict in Spain, according to the Spanish Tax Office. Table 1 shows the aggregate variation in compensations by economic sector ${ }^{2}$.

\footnotetext{
${ }^{2}$ Economic Sectors follow the classification of the Spanish Tax Office, while workers are categorized according to ILO rules. As a consequence, some regrouping is necessary to merge information. Complementary Professional Activities include logistics, telecommunications and other supporting services. Industrial Production includes all industries but manufacturing, i.e., extractive industries, energy production and waste management.
} 
TABle 1

Aggregate variation in total compensations March-April 2020 by economic sector (in percent)

\section{Economic sector}

\begin{tabular}{ll}
\hline Agriculture & 6.46 \\
\hline Other professional activities & -9.60 \\
\hline Industrial production & -11.45 \\
\hline Total for all sectors & $\mathbf{- 1 4 . 3 5}$ \\
\hline Arts \& education & -14.37 \\
\hline Financial services & -14.90 \\
\hline Retail & -14.99 \\
\hline Manufacturing & -20.20 \\
\hline Construction & -20.20 \\
\hline Real-estate & -22.62 \\
\hline Hospitality & -75.80 \\
\hline
\end{tabular}

Source: Author's estimations based on Spanish Tax Office statistics.

Exposed economic sectors are the following: manufacturing, construction, retail, hospitality, financial services, real-estate sector, education, and arts and recreation. Agriculture, industrial production (other than manufacturing: extracting industries, energy, and water supply...) and the so-called complementary professional activities (such as logistics, information and telecommunications...) are safe economic sectors, following this identification strategy.

The impact on income derived from this categorization and from the subsequent simulations is analyzed under three different low-income protection schemes. In the first protection scheme (Non Low-Income Benefit, NLIB), I consider gross income without any additional low-income protection transfer. That includes market income plus pensions and direct transfers (unemployment benefits, national family benefits, regional family benefits, non-contributory pensions and regularization from personal income taxes).

Renta Minima de Inserción (RMI) scheme includes all the transfers in the NLIB simulation, as well as the regional minimum income protection operating in Spain until the year 2020. RMI is a non-contributory transfer for residents between 25 and 65 years with no sufficient income. It is managed at the regional level and amounts, duration and conditions for elegibility vary across territories. For example, in Andalusia, Madrid or Valencia benefit was established as the $70 \%$ of the legal minimum wage, while in Murcia or Castilla y León it was 70\% of the benchmark indicator used by the Spanish administration for the allocation of all other social benefits (IPREM). All regions in Spain provided this benefit with different particularities (Gómez-Bengoechea, 2020). 
In the IMV scenario I substitute RMI for the newly approved, and still in its early operating phase, low-income state benefit. IMV centralizes the management of the transfer and establishes the same conditions and rules for the whole country, with no regard for households' regions. Its regulation is very similar to the RMI in terms of eligibility, but the duration and the amount of the benefits are higher in almost all cases.

Conditions for the identification of IMV beneficiaries are also means-tested. They include other limitations, such as age (between 23 and 65 years old), residence, household size and being actively looking for a job. There are some exceptions to these conditions due to reasons of social concern, such as being a victim of a sex crime or of gender-based violence.

Income limits and the amount of the benefit vary depending on the size and composition of each household. For a one-individual household, the benefit amount would be 5,538 euros, for incomes below 16,614 euros per year. For a two adults and one child household, the benefit amount would rise to 8,861 euros, for those incomes below 29,905 euros per year. Table A2 in the appendix section shows the benefit amounts for the national IMV and for the regional RMI schemes.

\section{RESULTS}

In this section, I present the composition of pre-crisis incomes and the impact of the COVID-19 economic shock on poverty, inequality, and the distribution of post-crisis income under the different low-income protection schemes.

\subsection{COMPOSITION OF PRE-CRISIS INCOME}

Figure 2 shows the composition of pre-crisis incomes across the entire distribution for each protection scheme. Income distribution is obtained from the original data in the ECV survey. I consider 5 income categories: public transfers, contributory pensions, government salaries (the three of them are public sector related), "safe" labor income and "at risk" labor income.

Data for the three protection schemes show the important role that public transfers play for the first deciles of the income distribution; they represent as much as $80 \%$ of the total income distribution for decile 1. The public sector, through transfers, contributory pensions, and salaries, generates around $30 \%$ of total income for deciles 2 to 8 .

At-risk income represents around $40 \%$ of total income for deciles 3 to 10 . Safe income behaves in a similar way, but it grows significantly for the first and last deciles. Initial deciles include incomes derived from essential low-skilled jobs, like agriculture or logistics (see table A3 in the appendix section for further details on each decile composition by individuals in each economic sector). The final deciles group workers whose income comes from positions in which remote working is more feasible (financial sector, for example) and with an available athome internet connection (Brussevich, Dabla-Norris and Khalid, 2020). 


\section{Figure 2}

Income composition under different protection schemes

(a) NLIB scenario

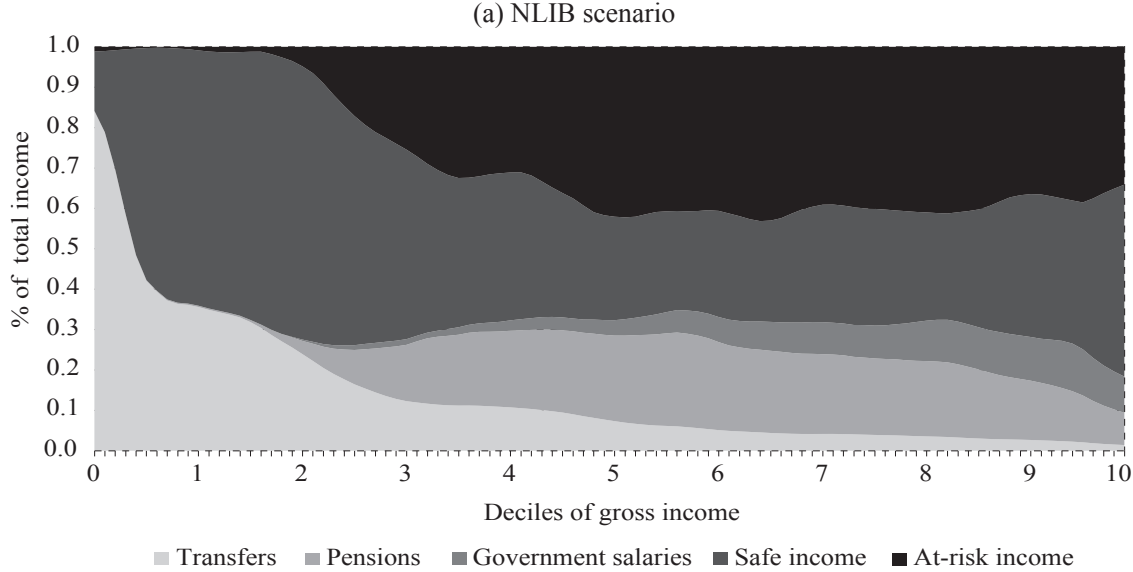

(b) RMI scenario

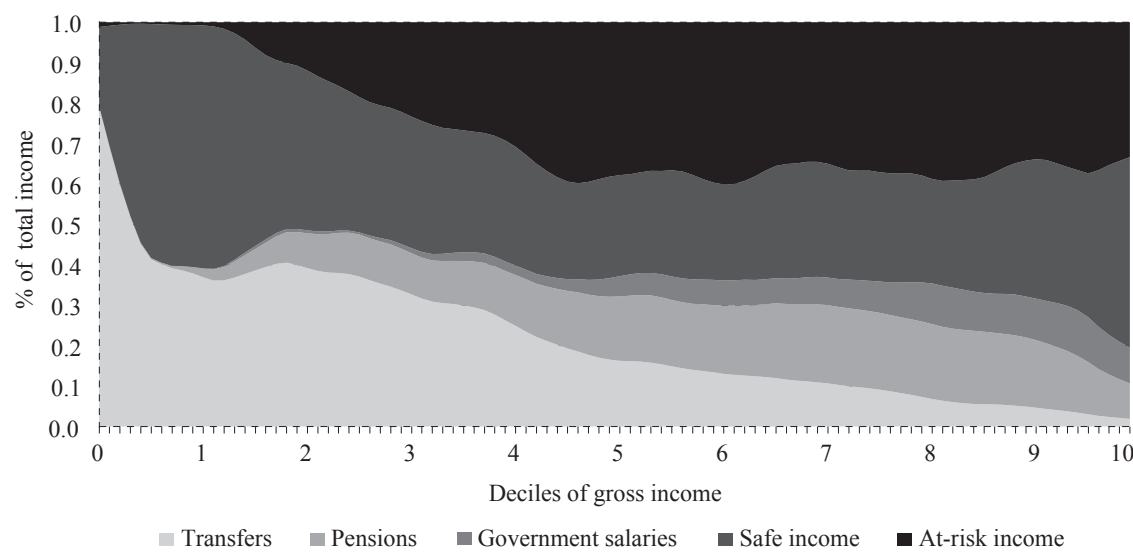

(c) IMV scenario

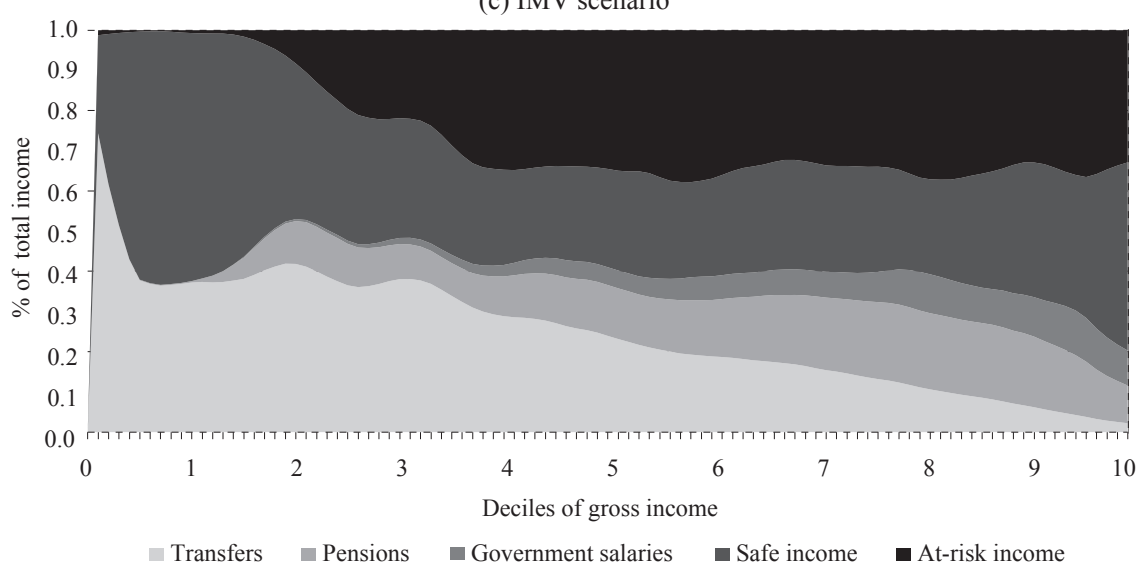

Source: Authors' estimations based on ECV data. 
The impact of RMI and IMV can be appreciated in deciles from 0 to 3 where there is a higher concentration of public transfers in comparison with NLIB. For the IMV scheme, public transfers represent a higher percentage of income than for RMI. Transfers fall below 20\% of total income after deciles 2, 4 and 6 in the NLIB, RMI and IMV simulations.

\subsection{STRESSING INCOMES}

To simulate the impact of the COVID-19 crisis on household income and the resulting evolution of inequality, poverty and minimum income guarantee schemes I stress at-risk incomes following Lustig et al. (2020). Table 2 shows the range of possible income losses when I increase the share of households that lose their atrisk income and the share of income lost for those households.

Cells in table 2 show the range of possible per capita household gross income losses (as a proportion of ex ante gross income) as we vary both the probability that households lose at-risk income (down the rows) and the share of that at-risk income they lose (across the columns). I vary both parameters from 0 to $100 \%$. The possible outcomes represent the variation of total per capita income; they range from near zero to almost $15 \%$ of pre-crisis income.

For example, the $10 \%-10 \%$ cell of this matrix shows the fall in income corresponding to the case in which $10 \%$ of the households (with at risk income) lose $10 \%$ of their income each; that cell corresponds with a $0.2 \%$ decrease in per capita gross income.

\section{TABLE 2}

Scenarios for income losses as a percentage of total household income

$\%$ of at-risk income lost

\begin{tabular}{|c|c|c|c|c|c|c|c|c|c|c|c|}
\hline & & 10 & 20 & 30 & 40 & 50 & 60 & 70 & 80 & 90 & 100 \\
\hline \multirow{10}{*}{ 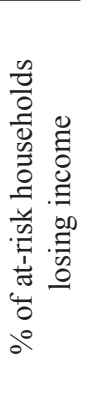 } & 10 & 0.2 & 0.3 & 0.5 & 0.6 & 0.8 & 0.9 & 1.1 & 1.2 & 1.4 & 1.5 \\
\hline & 20 & 0.3 & 0.6 & 0.9 & 1.2 & 1.5 & 1.8 & 2.1 & 2.4 & 2.7 & 3.0 \\
\hline & 30 & 0.5 & 0.9 & 1.4 & 1.9 & 2.4 & 2.8 & 3.3 & 3.8 & 4.2 & 4.7 \\
\hline & 40 & 0.6 & 1.2 & 1.9 & 2.5 & 3.1 & 3.7 & 4.3 & 4.9 & 5.6 & 6.2 \\
\hline & 50 & 0.8 & 1.5 & 2.3 & 3.1 & 3.9 & 4.6 & 5.4 & 6.2 & 6.9 & 7.7 \\
\hline & 60 & 0.9 & 1.8 & 2.8 & 3.7 & 4.6 & 5.5 & 6.4 & 7.4 & 8.3 & 9.2 \\
\hline & 70 & 1.1 & 2.1 & 3.2 & 4.3 & 5.3 & 6.4 & 7.5 & 8.5 & 9.6 & 10.7 \\
\hline & 80 & 1.2 & 2.4 & 3.6 & 4.8 & 6.0 & 7.2 & 8.4 & 9.6 & 10.8 & 12.0 \\
\hline & 90 & 1.3 & 2.7 & 4.0 & 5.4 & 6.7 & 8.1 & 9.4 & 10.7 & 12.1 & 13.4 \\
\hline & 100 & 1.5 & 3.0 & 4.4 & 5.9 & 7.4 & 8.9 & 10.4 & 11.8 & 13.3 & 14.8 \\
\hline
\end{tabular}

Source: Author's estimations based on ECV data.

I narrow the focus of the article on those cells that have income losses similar to Spain's GDP contraction in the year 2020 (-10.8\%). I have highlighted them in table 2. They form an "iso-loss" curve that runs diagonally through the table. I choose the two results where either the smallest proportion of households lose much income (upper right, $90 \%$ of at-risk income lost for $80 \%$ of the households 
with at-risk income), or the largest proportion of households lose smaller amounts of income (lower left, $80 \%$ of at-risk income lost for $90 \%$ of the households with at-risk income).

I will refer to them as the "concentrated" and "dispersed" losses scenarios. My analysis is focused on those two scenarios for the three different protection schemes already explained. The matrix in table 3 summarizes the contraction scenarios and protection schemes under which I present the results in this section.

\section{TABLE 3}

Low-income protection schemes and income contraction scenarios

Income contraction scenarios

\begin{tabular}{llll}
\hline $\begin{array}{l}\text { Low-income } \\
\text { protection schemes }\end{array}$ & $\begin{array}{l}\text { Concentrated losses under NLIB } \\
\text { Concentrated losses under RMI }\end{array}$ & & Dispersed losses under NLIB \\
\cline { 2 - 3 } & Dispersed losses under RMI \\
\hline
\end{tabular}

\subsection{IMPACT ON POVERTY AND INEQUALITY}

Tables 4 and 5 show the incidence on poverty of concentrated and dispersed losses scenarios using four poverty thresholds: the US \$1.9, \$3.2 and \$5.5 a day international poverty lines (in 2011 purchasing power parity), as well as for the national poverty rate. National poverty rate line is defined as the percentage individuals living below $60 \%$ of the median income. I test the evolution of those magnitudes both for the concentrated and dispersed losses scenarios under the three aforementioned protection mechanisms.

\section{TABLE 4}

Concentrated losses scenarios, incidence on different poverty lines (percentage of population living under each line)

\section{Concentrated losses (90-80)}

\begin{tabular}{|c|c|c|c|c|}
\hline NUBI & Pre-COVID & Post-COVID & Change & New poor \\
\hline $1.9 \$ /$ day & 0.75 & 0.89 & 0.14 & 67,682 \\
\hline $3.2 \$$ / day & 0.80 & 1.01 & 0.21 & 101,286 \\
\hline 5.5 \$ / day & 0.86 & 1.19 & 0.34 & 159,502 \\
\hline National poverty line & 6.70 & 8.06 & 1.36 & 643,688 \\
\hline RMI & Pre-COVID & Post-COVID & Change & New poor \\
\hline $1.9 \$ /$ day & 0.43 & 0.56 & 0.13 & 61,529 \\
\hline $3.2 \$ /$ day & 0.46 & 0.65 & 0.19 & 88,507 \\
\hline 5.5 \$ / day & 0.48 & 0.80 & 0.32 & 152,876 \\
\hline National poverty line & 6.49 & 8.01 & 1.52 & 719,416 \\
\hline \multicolumn{5}{|l|}{ RMV } \\
\hline $1.9 \$ /$ day & 0.45 & 0.53 & 0.08 & 37,391 \\
\hline $3.2 \$ /$ day & 0.49 & 0.58 & 0.09 & 42,124 \\
\hline $5.5 \$$ / day & 0.51 & 0.67 & 0.16 & 74,781 \\
\hline National poverty line & 6.18 & 7.69 & 1.51 & 716,103 \\
\hline
\end{tabular}

Source: Author's estimations based on ECV data. 
Dispersed losses scenarios, incidence on different poverty lines (percentage of population living under each line)

Dispersed losses (80-90)

\begin{tabular}{|c|c|c|c|c|}
\hline NUBI & Pre-COVID & Post-COVID & Change & New poor \\
\hline $1.9 \$ /$ day & 0.75 & 0.85 & 0.10 & 48,750 \\
\hline $3.2 \$ /$ day & 0.80 & 0.93 & 0.13 & 59,162 \\
\hline $5.5 \$ /$ day & 0.86 & 1.02 & 0.16 & 74,781 \\
\hline National poverty line & 6.70 & 8.13 & 1.43 & 678,712 \\
\hline \multicolumn{5}{|l|}{ RMI } \\
\hline $1.9 \$ /$ day & 0.43 & 0.53 & 0.11 & 50,643 \\
\hline $3.2 \$ /$ day & 0.46 & 0.58 & 0.12 & 58,689 \\
\hline $5.5 \$ /$ day & 0.48 & 0.64 & 0.16 & 77,621 \\
\hline National poverty line & 6.49 & 8.08 & 1.59 & 753,493 \\
\hline \multicolumn{5}{|l|}{ RMV } \\
\hline $1.9 \$ /$ day & 0.45 & 0.50 & 0.05 & 22,245 \\
\hline $3.2 \$ /$ day & 0.49 & 0.55 & 0.06 & 29,345 \\
\hline $5.5 \$$ / day & 0.51 & 0.58 & 0.08 & 35,497 \\
\hline National poverty line & 6.18 & 7.76 & 1.58 & 747,814 \\
\hline
\end{tabular}

Source: Author's estimations based on ECV data.

Absolute poverty rates are higher for concentrated than for dispersed losses under the three protection schemes. For the RMI scheme, poverty rates range from $0.56 \%$ of the population for the $\$ 1.9$ a day line to $0.8 \%$ at $\$ 5.5$ a day. For dispersed losses, those same rates are $0.53 \%$ and $0.67 \%$. Similar patterns can be observed for the NLIB and IMV cases, with higher poverty rates for the concentrated losses scenario. Poverty rates under the national poverty line show a similar behavior for concentrated and dispersed losses scenarios.

RMI and IMV reduce poverty significantly compared to the absence of any minimum income guarantee scheme. For the RMI scheme under the concentrated losses simulation, the number of new poor individuals would be 61,529 for the $\$ 1.9$ line. There would be 37,391 new individuals falling behind that same poverty line under the IMV scheme.

IMV shows a better performance than RMI under all simulations. This suggests that the changes in eligibility conditions and amounts generated by the centralization of the benefit improve aggregate results. Poverty increase is lower without any protection than under the RMI scheme for the national poverty line, as well. This counterintuitive result can be explained by the fact that many households may not get access to the benefit due to non-income related conditions (potential beneficiaries must prove they have applied and been rejected for all possible benefits before asking for IMV or RMI) or do not even apply for it, due to the disincentives generated by the bureaucratic costs attached to the whole process (Ayala et al., 2021; Natili, 2018) or the impossibility of gathering all the necessary documents. 
Inequality, measured through the Gini Index, shows a better performance under IMV than under RMI for the three protection schemes. Table 6 shows that Gini Index rises from 0.45 before the COVID-19 shock to 0.51 under RMI, for concentrated losses, and to 0.493 , for dispersed losses. For the IMV protection, Gini varies from 0.434 to 0.494 in the concentrated losses and to 0.477 for dispersed losses simulation, before and after the income shock.

Inequality is much higher under NLIB simulations. Gini Index would rise from 0.498 for pre-crisis income to $0.550-0.567$ for the dispersed or concentrated losses post-crisis scenarios. These results are consistent with (Gomez-Bengoechea and Quan, 2019) for gross income, which coincide with those found by (del Valle Navas and de la Cruz, 2018) as well. Different methodological approaches make direct comparison with other available estimations non-informative. Further results on the Gini Index evolution under the different income-stress simulations can be found in figure 4 in the appendix section.

\section{TABle 6}

Gini Index for concentrated and dispersed losses under different protection schemes

\section{Concentrated losses}

\begin{tabular}{|c|c|c|c|}
\hline & Ex ante & Ex post & $\%$ change \\
\hline NUBI & 0.498 & 0.567 & 13.9 \\
\hline RMI & 0.450 & 0.510 & 13.3 \\
\hline RMV & 0.434 & 0.494 & 13.9 \\
\hline \multicolumn{4}{|c|}{ Dispersed losses } \\
\hline NUBI & 0.498 & 0.550 & 10.5 \\
\hline RMI & 0.450 & 0.493 & 9.6 \\
\hline RMV & 0.434 & 0.477 & 10.0 \\
\hline
\end{tabular}

Source: Authors' estimations based on ECV data.

\subsection{IMPACT ON INCOME DISTRIBUTION}

Figure 3 shows income evolution for each decile of the income distribution relative to gross income. Four big conclusions can be derived from it. The first one is that all individuals are worse off after the impact of the crisis for every decile, even if losses are not uniformly distributed through the entire distribution.

The second one is that income losses are much larger under the concentrated losses scenario. Income evolution captured in figure 3(a) shows that there is a group of individuals below decile 1 that do not get any benefit for different reasons, as already mentioned. For them, losses range from $15 \%$ to $40 \%$ on the three low-income protection schemes.

Around decile 1, income losses recover to $10 \%$ thanks to the role of public transfers and other social measures to alleviate income losses. Largest income falls can be found between decile 1 and decile 5. For those individuals, income contraction 
would be between $40 \%$ and $20 \%$ under the RMI and IMV schemes. In the NLIB scenario, income would be reduced by $60 \%$ for individuals between decile 2 and 3. After decile 5, losses would moderate and almost converge beyond decile 9 under the three protection scenarios.

Figure 3

Incidence curves for at-risk incomes

(a) Concentrated losses

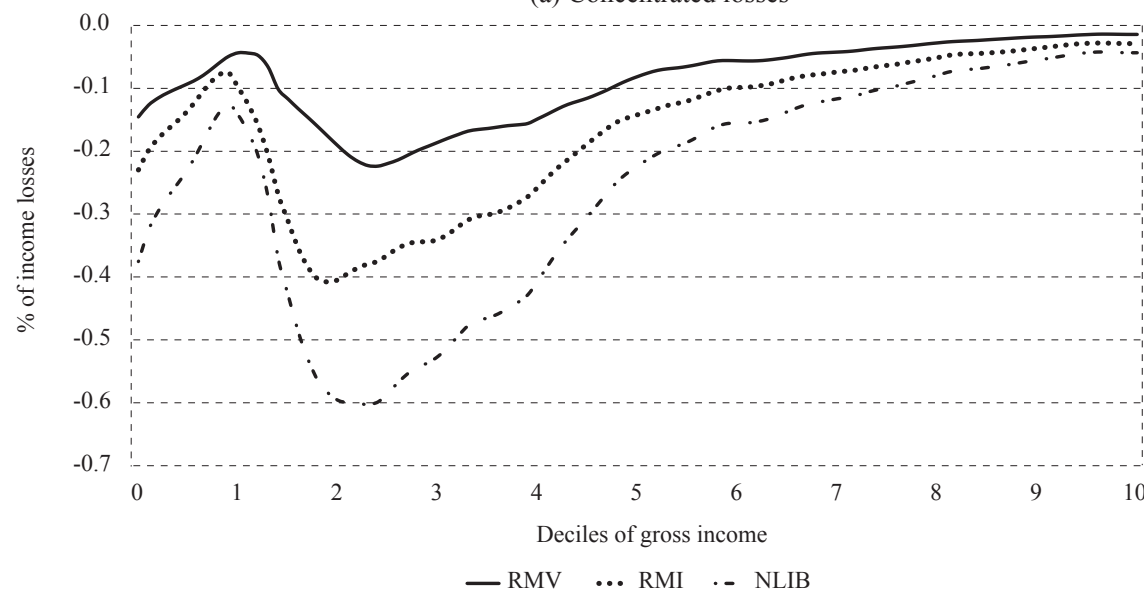

(b) Dispersed losses

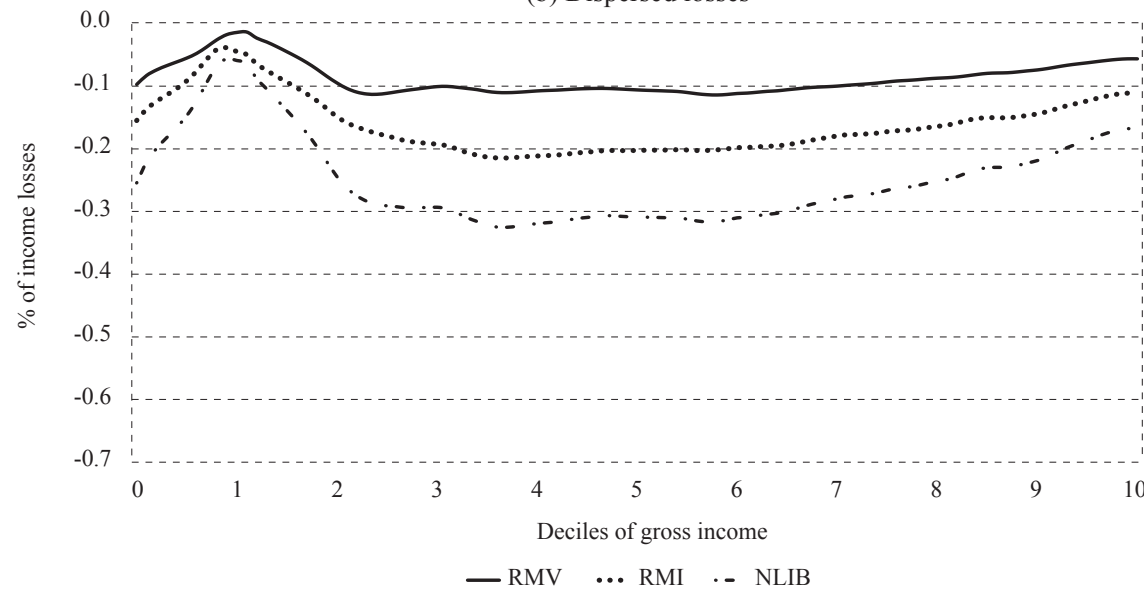

Source: Author's estimations based on ECV data.

The third conclusion is derived from the dispersed losses simulation; income reduction is less profound and more evenly distributed. Under the NLIB scheme, income falls around $30 \%$ from decile 2 to decile 7 . This contraction is half of the reduction experienced under concentrated losses. Both simulations show a similar evolution for the first deciles ( 0 to 2 ), but the reduction in losses recovers faster under the concentrated losses scenario. 
Finally, results show that low-income benefits limit income losses. IMV is more effective than RMI but, in both cases, they curb the impact of income losses for potential beneficiaries. The relative homogeneity of at-risk and safe incomes for the entire distribution and the fact that contributory pensions and salaries earned in the public sector are spread along the entire income distribution explain the similar decrease in income for middle- and high-income groups. Results show a relatively small impact on high-skilled white-collar workers' that can better adapt to lockdowns through online work (Belzunegui-Eraso and Erro-Garcés, 2020), and whose income is in deciles 8 and 9 (see table A3 in the appendix).

From the point of view of income mobility between social groups, post-shock income evolution offers interesting results as well. Table 7 shows the downward mobility of high and middle classes caused by the COVID-19 crisis. Income groups are defined as follows: poor individuals are those living below $\$ 5.50$ per day. Middle class captures income between $\$ 5.50$ and $\$ 57.60$ per day. High income is established above the $\$ 57.60$ per day threshold. This identification strategy has been established following Lustig et al. (2020) criteria.

Almost $6 \%$ of high-income individuals would fall into the middle class in the concentrated losses scenario. $2 \%, 1.2 \%$ and $0.8 \%$ of individuals would decline from middle class to poverty under the three protection schemes considered. For dispersed losses, downward mobility is much lower: around $3.5 \%$ of individuals would move from high to middle income groups, and $1 \%, 0.6 \%$ and $0.4 \%$ would do it from middle to low income.

\section{TABLE 7}

Income mobility by income group (in percent)

Concentrated losses

Dispersed losses

\begin{tabular}{|c|c|c|c|c|}
\hline & $\begin{array}{l}\text { From high } \\
\text { to middle }\end{array}$ & $\begin{array}{c}\text { From middle } \\
\text { to poor }\end{array}$ & $\begin{array}{l}\text { From high } \\
\text { to middle }\end{array}$ & $\begin{array}{l}\text { From middle } \\
\text { to poor }\end{array}$ \\
\hline NUBI & 5.7 & 2.0 & 3.7 & 1.0 \\
\hline RMI & 5.9 & 1.2 & 3.6 & 0.6 \\
\hline IMV & 5.9 & 0.8 & 3.3 & 0.4 \\
\hline
\end{tabular}

Source: Author's estimations based on ECV data.

\section{DISCUSSION AND POLICY IMPLICATIONS}

This article tackles the impact of the COVID crisis on income distribution and the role played by low-income benefits to curb inequality and poverty increases. Results contribute to the literature showing how income falls are not evenly distributed along the entire distribution and bring lessons that should be taken into account for an optimal design of low-income benefits. The first implication derived from the results obtained is that higher amounts and a centralized design of benefits could help to lower poverty rates and inequality, under certain conditions and with some limitations, as will be explained in the following lines. The different simulations have shown that IMV is more pro-poor and pro-equality than RMI and the NLIB benchmark scheme. 
The second one is that higher benefits will not fix the problems for the middle classes by themselves. Even if the most affected income groups in the simulations are roughly in the middle and higher middle classes (deciles 2 to 7, approximately), the literature shows the role played by globalization (Asha, 2018; Milanovic, 2012) and mechanization on the stagnation of labor income in advanced countries; this is a problem area that seems to go beyond traditional fiscal policies.

Third, it is necessary to establish mechanisms that can ease and evenly share the income adjustments that future crises may bring. Income contraction derived from the impact of COVID generates more new poor individuals for the concentrated than for the dispersed losses scenario. Inequality shows a similar pattern; the dispersed losses scenario shows lower inequality increases. Labor market adjustment, through wages and not necessarily through firms' downsizing (Kahn, 2012), should help in that regard. Remote work programs, when possible, would also reduce impacts on income of future crises like the one analyzed in this article, as the evolution and composition of incomes for the latest deciles suggests.

Finally, more than $60 \%$ of Spanish income depends on the public sector in one way or another. The public sector, through transfers, contributory pensions, and salaries generates around $40 \%$ of total income for deciles 2 to 8 . At the same time, income composition reveals that at-risk income (thus, potentially in need of public help), represents around $30 \%$ of total income for deciles 3 to 10 .

The original budget for the IMV program was 2,890 million euros for the year 2021 (AIREF, 2020). Results suggest an increase of its cost derived from the new poor individuals under the national poverty line (which is used as a reference for the IMV program) between $24.4 \%$ for the concentrated and $25.6 \%$ for the dispersed losses scenarios. The total cost of the IMV program would rise to 3,628 million euros for the concentrated losses scenario and to 3,594 million euros for the dispersed losses scenario. This extra pressure on public finance, also coming from other social programs, may require from tax rises that they maintain lowincome protection policies in a context of weak revenues.

As a consequence of the previous implications, an improvement of the current design of low-income benefits in Spain would require, first, the same eligibility conditions and minimum benefit amounts at the national level, as in the IMV scheme. However, the particularities documented in the literature (see GómezBengoechea, 2020; and del Valle Navas and de la Cruz, 2018) suggest the necessity of adapting the conditionality on income thresholds and on the amount of the benefit to each region's circumstances.

Some of the left-behind individuals fall below the means-tested conditions established for receiving low-income benefits, but do not get access to it due to bureaucratic costs, information barriers and other formal reasons. Without a careful policy implementation, increasing amounts may even generate higher inequality. It is 
critical to make those benefits available for those individuals in need that do not receive the benefit (Ayala et al., 2021; Natili, 2018). A simplification of the bureaucratic process, the use of municipal agencies by the central government to reach potential beneficiaries and the establishment of offices to manage the submission and approval of applications for benefits would help in that regard.

\section{CONCLUSIONS}

The impact of COVID-19 on the whole world has been dramatic, both in terms of lives taken and income losses. Countries with a more developed welfare state should be able to cope better with this extreme situation through their structural and ad-hoc policies.

The case of Spain is a paradigmatic one for the study of this problematic. The recent approval of the IMV (a means-tested national transfer paid to lowest incomes) allows me to test its role on smoothing the impact of the crisis and its performance relative to previously existing RMI (like IMV, but at the regional level) and to the hypothetical absence of any minimum income state protection schemes.

Results show that the worst effects of the COVID-19 crisis and the potential lockdowns it could still bring are not on the poorest, but those in the middle and wealthy groups of the ex-ante income distribution. Under all microsimulations, IMV is more efficient in curbing poverty and inequality than RMI. Without any of these protection policies, inequality and poverty rates would be higher.

The paper has some caveats that should be tackled in the upcoming research on this topic. First, as has been mentioned, the microsimulations do not take into account behavioral responses or general equilibrium effects, so they yield firstorder effects only. Second, the depth and duration of the crisis is still uncertain. Third, results depend on the specific assumptions we make about income sources that are "at risk" and the extent to which losses are concentrated or dispersed across households. Fourth, I am assuming that all individuals fulfilling the conditions to get the benefits are, in fact, receiving them. This is a limitation common to this kind of literature. Finally, I focus my analysis at the national level; regional and local differences could also be exploited in future articles.

The challenge for the Spanish state is twofold. First, it needs to fine tune IMV performance and design; preliminary government data show that the number of recipients is well below initial projections. Second, it may be necessary to raise taxes and to reduce expenditure under other policies to maintain protection schemes in the context of lower public revenues. Furthermore, low productivity and the current demographic dynamic could trigger an austerity debate in the aftermath of the COVID-19 crisis.

\section{Disclosure statement}

No potential conflict of interest was reported by the author. 


\section{REFERENCES}

1. Aguilar-Hendrickson, M. and Arriba González de Durana, A., 2020. Out of the wilderness? The coming back of the debate on minimum income in Spain and the Great Recession. Social Policy \& Administration, 54(4), pp. 556-573. https://doi.org/10.1111/spol.12605

2. AIREF, 2020. Informe sobre las líneas fundamentales de los presupuestos de las Administraciones Publicas 2021. Tech. Rep. No. 29/20.

3. Asha, S., 2018. Richard Baldwin: The Great Convergence: Information Technology and the New Globalization. New Global Studies, 12(2), pp. 297-300. https://doi.org/10.1515/ngs-2018-0004

4. Aspachs, O. [et al.], 2020. Real-time inequality and the welfare state in motion: Evidence from COVID-19 in Spain. Economics Working Papers, No. 1734. https://doi.org/10.1371/journal.pone.0249121

5. Ayala, L. and Cantó, O., 2020. The redistributive effects of social benefits and taxes: a review of the current situation. Social Observatory of "la Caixa", April 2020.

6. Ayala, L., [et al.], 2021. The effectiveness of minimum income benefits in poverty reduction in Spain. International Journal of Social Welfare, 30(2), pp. 152-169. https://doi.org/10.1111/ijsw.12447

7. Baena-Díez, J. M. [et al.], 2020. Impact of COVID-19 outbreak by income: hitting hardest the most deprived. Journal of public health, 42(4), pp. 698703. https://doi.org/10.1093/pubmed/fdaa136

8. Belzunegui-Eraso, A. and Erro-Garcés, S., 2020. Teleworking in the Context of the Covid-19 Crisis. Sustainability, 12(9). https://doi.org/10.3390/su12093662

9. BOE, 2020. Real Decretoley 20/2020, de 29 de mayo, por el que se establece el ingreso mínimo vital. Boletín Oficial del Estado, pp. 36022-36065. https:// doi.org/10.36576/summa. 8558

10. Bourguignon, F. and Spadaro, A., 2006. Microsimulation as a Tool for Evaluating Redistribution Policies. ECINEQ, Society for the Study of Economic Inequality Working Papers, No. 20.

11. Bourguignon, F., 2011. Non-anonymous growth incidence curves, income mobility and social welfare dominance. The Journal of Economic Inequality, 9, pp. 605-627. https://doi.org/10.1007/s10888-010-9159-7

12. Brussevich, M., Dabla-Norris, E. and Khalid, S., 2020. Teleworking is Not Working for the Poor, the Young, and the Women. IMF Blog, July 7, 2020.

13. Clark, A. E., D'Ambrosio, C. and Lepinteur, A., 2020. The Fall in Income Inequality during COVID-19 in Five European Countries. ECINEQ, Society for the Study of Economic Inequality Working Papers, No. 565.

14. Deaton, A., 2021. COVID-19 and Global Income Inequality. NBER Working Paper, No. 28392. https://doi.org/10.3386/w28392

15. Del Valle Navas, M. and De La Cruz, N. L., 2018. Spain: Euromod Report 2015-2018. Brussells: European Commission. 
16. Förster, M. and Whiteford, P., 2009. How much Redistribution do Welfare States Achieve? The Role of Cash Transfers and Household Taxes. CESifo DICE Report, 7(3), pp. 34-41.

17. Gómez-Bengoechea, G. and Quan, S., 2019. Fiscal Redistribution in Spain in 2017. Commitment to Equity Institute Technical report.

18. Gómez-Bengoechea, G., 2020. Fiscal Incidence in Spain in 2016. CEQ Working Paper, No. 102.

19. Han, J., Meyer, B. D. and Sullivan, J. X., 2020. Income and Poverty in the COVID-19 Pandemic. NBER Working Paper, No. 27729.

20. Hernández, A., Picos, F. and Riscado, S., 2020. Moving towards fairer regional minimum income schemes in Spain. JRC Working Papers on Taxation and Structural Reforms, No 4/2020.

21. Horvarth, B. and Wignaraja, K., 2020. Universal basic income is the answer to the inequalities exposed by COVID-19. World Economic Forum, 17 April 2020.

22. Immervoll, H. and Richardson, L., 2011. Redistribution Policy and Inequality Reduction in OECD Countries: What Has Changed in Two Decades? OECD Social, Employment and Migration Working Papers, No. 122. https://doi. org/10.1787/5kg5dlkhjq0x-en

23. Johnson, A. F. and Roberto, K. J., 2020. The COVID-19 pandemic: Time for a universal basic income? Public Administration and Development, 40(4), pp. 232-235. https://doi.org/10.1002/pad.1891

24. Johnson, M. [et al.], 2020. Mitigating social and economic sources of trauma: the need for Universal Basic Income during the Coronavirus Pandemic. Psychological Trauma Theory Research Practice and Policy, 12(S1), S191-S192. https://doi.org/10.1037/tra0000739

25. Kahn, L. M., 2012. Labor market policy: A comparative view on the costs and benefits of labor market flexibility. Journal of Policy Analysis and Management, 31(1), pp. 94-110. https://doi.org/10.1002/pam.20602

26. Keid, M. G., 1954. Income Redistribution and Social Policy: A Set of Studies. London: Jonathan Cape, 1954. 25s. net. The ANNALS of the American Academy of Political and Social Science, 295(1), p. 165. https://doi.org/10.1177/ 000271625429500142

27. Lakner, C. [et al.], 2019. How Much Does Reducing Inequality Matter for Global Poverty? Policy Research Working Paper Series, No. 8869. https://doi. org/10.1596/1813-9450-8869

28. Lambert, P. J., 1992. The Distribution and Redistribution of Income. London: Macmillan Education.

29. Lustig, N. [et al.], 2020. The impact of Covid-19 lockdowns and expanded social assistance on inequality, poverty and mobility in Argentina, Brazil, Colombia and Mexico. Center for Global Development Working Paper, No. 556.

30. Lustig, N. and Pabon, V. M., 2020. The Impact of COVID-19 Economic Shock on Inequality and Poverty in Mexico. Tulane University, Department of Economics Working Papers, No. 2014. 
31. Lustig, N., 2018. Commitment to Equity Handbook. A Guide to Estimating the Impact of Fiscal Policy on Inequality and Poverty. Tulane University: Department of Economics.

32. Lustig, N., Pessino, C. and Scott, J., 2014. The Impact of Taxes and Social Spending on Inequality and Poverty in Argentina, Bolivia, Brazil, Mexico, Peru, and Uruguay: Introduction to the Special Issue. Public Finance Review, 42(3), pp. 287-303. https://doi.org/10.1177/1091142113506931

33. Milanovic, B. (ed.), 2012. Globalization and Inequality. Cheltenham, UK: Edward Elgar Publishing Limited.

34. Musgrave, R. A. [et al.], 1951. Distribution of tax payments by income groups: a case study for 1948. National Tax Journal, 4(1), pp. 1-53. https://doi.org/10.1086/ ntj41770954

35. Musgrave, R. A., 1959. The Theory of Public Finance: A Study in Public Economy. New York: McGraw-Hill.

36. Musgrave, R. A., Case, K. E. and Leonard, H., 1974. The Distribution of Fiscal Burdens and Benefits. Public Finance Quarterly, 2(3), pp. 259-311. https://doi. org/10.1177/109114217400200301

37. Natili, M., 2018. Explaining different trajectories of minimum income schemes: Groups, parties and political exchange in Italy and Spain. Journal of European Social Policy, 28(2), pp. 116-129. https://doi.org/10.1177/0958928717707272

38. Pechman, J. A., 1985. Who paid the taxes, 1966-85? Washington, D.C.: Brookings Institution.

39. Pollán, M. [et al.], 2020. Prevalence of SARS-CoV-2 in Spain (ENE-COVID): a nationwide, population-based seroepidemiological study. The Lancet, 396(10250), pp. 535-544. https://doi.org/10.1016/S0140-6736(20)31483-5

40. Ravallion, M., 2003. Measuring Aggregate Welfare in Developing Countries: How Well Do National Accounts and Surveys Agree? The Review of Economics andStatistics, 85(3), pp.645-652.https://doi.org/10.1162/003465303322369786

41. Tax Foundation, 1967. Allocating Tax Burdens and Government Benefits by In-come Class. Government Finance Brief, No. 8.

42. Widerquist, K., 2013. Basic Income: An Anthology of Contemporary Research. John Wiley \& Sons Incorporated. 


\section{TABLe A1}

Gini Index, poverty rates and social spending

\begin{tabular}{|c|c|c|c|}
\hline Country & Gini Index & Poverty rates & $\begin{array}{c}\text { Social spending } \\
\text { (\% of GDP) }\end{array}$ \\
\hline Austria & 0.28 & 9.4 & 26.9 \\
\hline Belgium & 0.26 & 8.2 & 28.9 \\
\hline Canada & 0.30 & 11.8 & 18.0 \\
\hline Chile & 0.46 & 16.5 & 11.4 \\
\hline Czech Republic & 0.25 & 6.1 & 19.2 \\
\hline Costa Rica & 0.50 & 19.9 & 12.2 \\
\hline Denmark & 0.26 & 6.1 & 28.3 \\
\hline Germany & 0.29 & 10.4 & 25.9 \\
\hline Estonia & 0.31 & 16.3 & 17.7 \\
\hline Finland & 0.27 & 6.5 & 29.1 \\
\hline France & 0.30 & 8.5 & 31.0 \\
\hline Great Britain & 0.37 & 11.7 & 20.6 \\
\hline Greece & 0.31 & 12.1 & 24.0 \\
\hline Hungary & 0.29 & 8.0 & 18.1 \\
\hline Ireland & 0.29 & 9.0 & 13.4 \\
\hline Israel & 0.25 & 16.9 & 16.3 \\
\hline 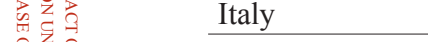 & 0.33 & 13.9 & 28.2 \\
\hline Latvia & 0.34 & 17.5 & 16.4 \\
\hline Lithuania & 0.36 & 15.5 & 16.7 \\
\hline Luxembourg & 0.32 & 11.4 & 21.6 \\
\hline Mexico & 0.42 & 16.6 & 7.5 \\
\hline Netherlands & 0.29 & 8.3 & 16.1 \\
\hline Norway & 0.26 & 8.4 & 25.3 \\
\hline Poland & 0.28 & 9.8 & 21.3 \\
\hline Portugal & 0.32 & 10.4 & 22.6 \\
\hline Slovakia & 0.24 & 7.7 & 17.7 \\
\hline Slovenia & 0.25 & 7.5 & 21.1 \\
\hline South Korea & 0.35 & 16.7 & 12.2 \\
\hline Spain & 0.33 & 14.2 & 24.7 \\
\hline Sweden & 0.28 & 8.9 & 25.5 \\
\hline Switzerland & 0.30 & 9.2 & 16.7 \\
\hline United States & 0.39 & 17.8 & 18.7 \\
\hline
\end{tabular}

Note: OECD Countries, 2019 or latest year with available data.

Source: Author's estimations based on OECD statistics. 
TABLE A2

Minimum and maximum benefit amounts: RMI regional and IMV national low income protection schemes (in $€$ )

Protection scheme and region

RMI Andalucía

RMI Aragón

RMI Asturias

RMI Baleares

RMI Canarias

RMI Cantabria

RMI Castilla - La Mancha

RMI Castilla y León

RMI Cataluña

RMI Ceuta

RMI Extremadura

RMI Galicia

RMI La Rioja

RMI Madrid

RMI Melilla

RMI Murcia

RMI Navarra

RMI Valencia

IMV National
RMI País Vasco

Min. benefit amount

Max. benefit amount

\begin{tabular}{|c|c|}
\hline $5,287.44$ & $4,541.88$ \\
\hline $5,892.00$ & $5,892.00$ \\
\hline $5,315.52$ & $3,455.04$ \\
\hline $5,178.36$ & $4,140.60$ \\
\hline $5,745.24$ & $2,267.76$ \\
\hline $5,163.24$ & $2,904.36$ \\
\hline $5,357.40$ & $4,079.76$ \\
\hline $5,168.40$ & $3,221.88$ \\
\hline $7,248.00$ & $6,216.00$ \\
\hline $3,600.00$ & $1,440.00$ \\
\hline $5,163.24$ & $3,549.73$ \\
\hline $5,084.16$ & $4,067.28$ \\
\hline $5,163.24$ & $2,904.36$ \\
\hline $4,800.00$ & $5,722.20$ \\
\hline $5,503.68$ & $3,669.12$ \\
\hline $5,163.24$ & $4,517.88$ \\
\hline $7,329.60$ & $7,329.60$ \\
\hline $3,090.84$ & $6,623.04$ \\
\hline $7,733.88$ & $4,130.64$ \\
\hline $5,544.00$ & $6,636.00$ \\
\hline
\end{tabular}

Source: Author's estimations based on ECV data. 
540

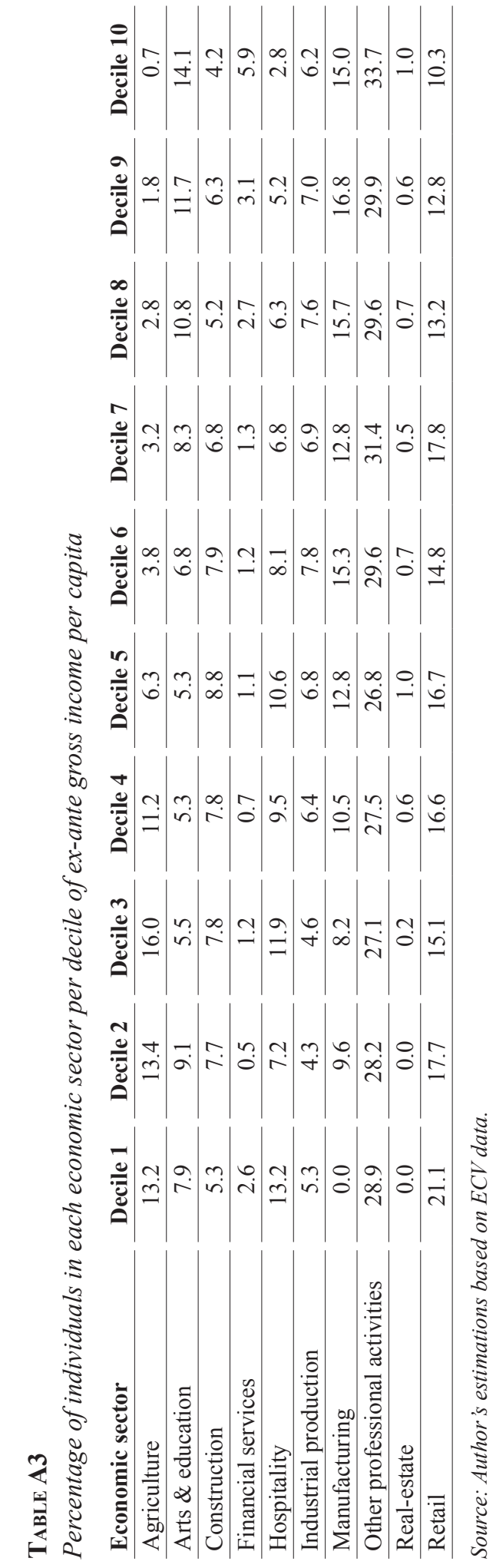

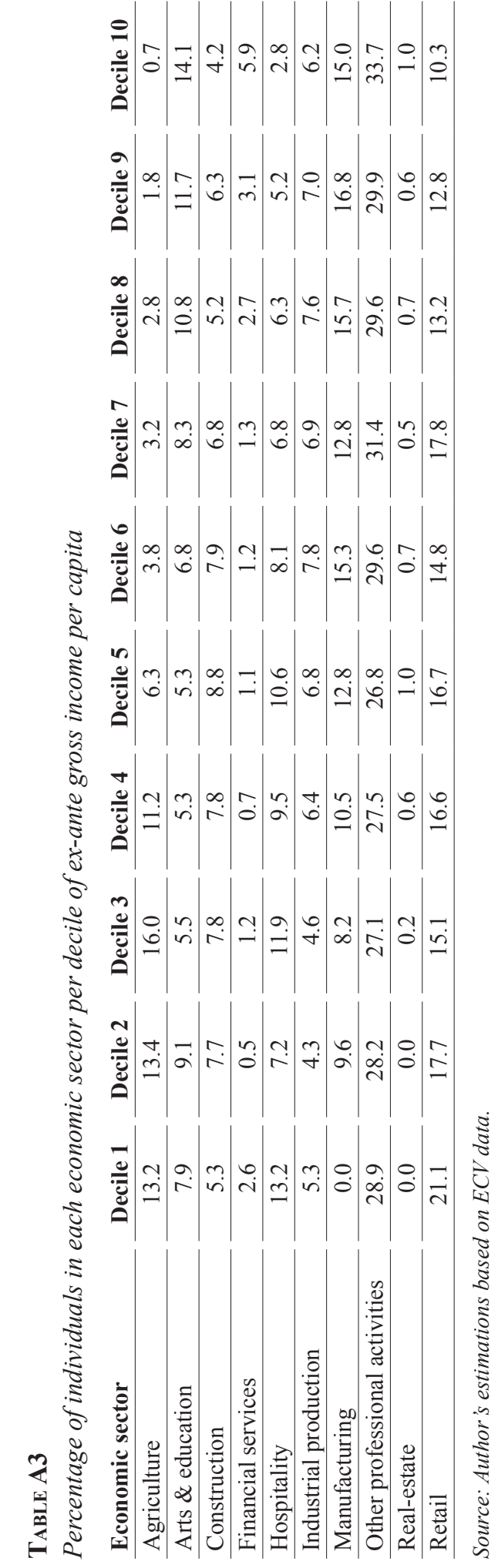

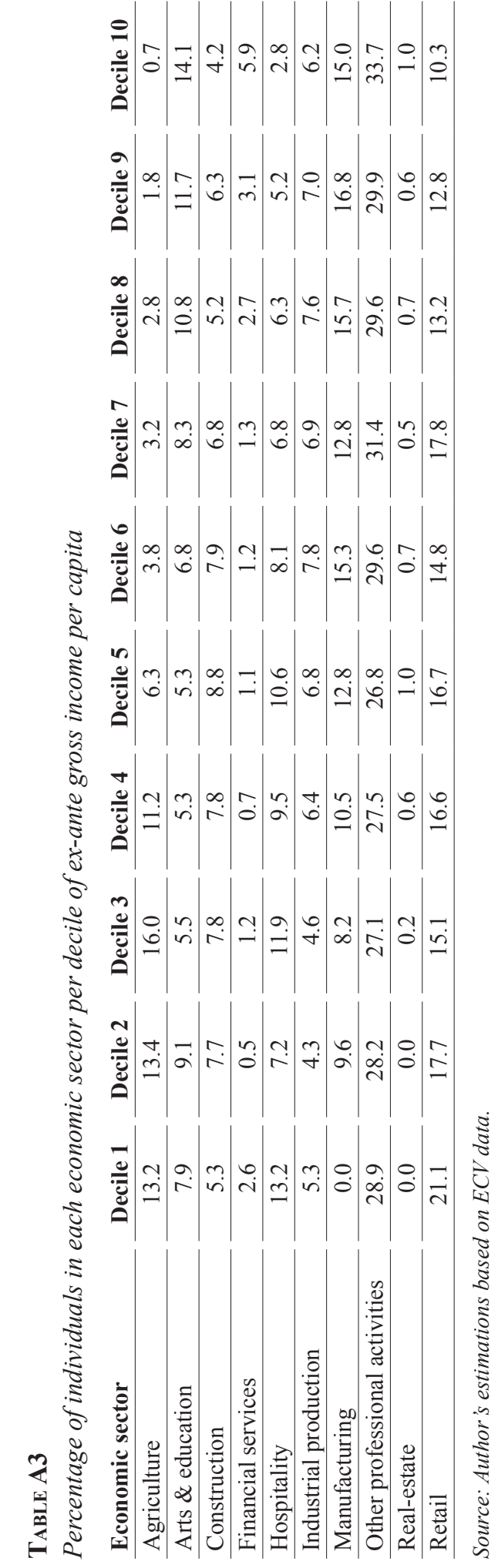

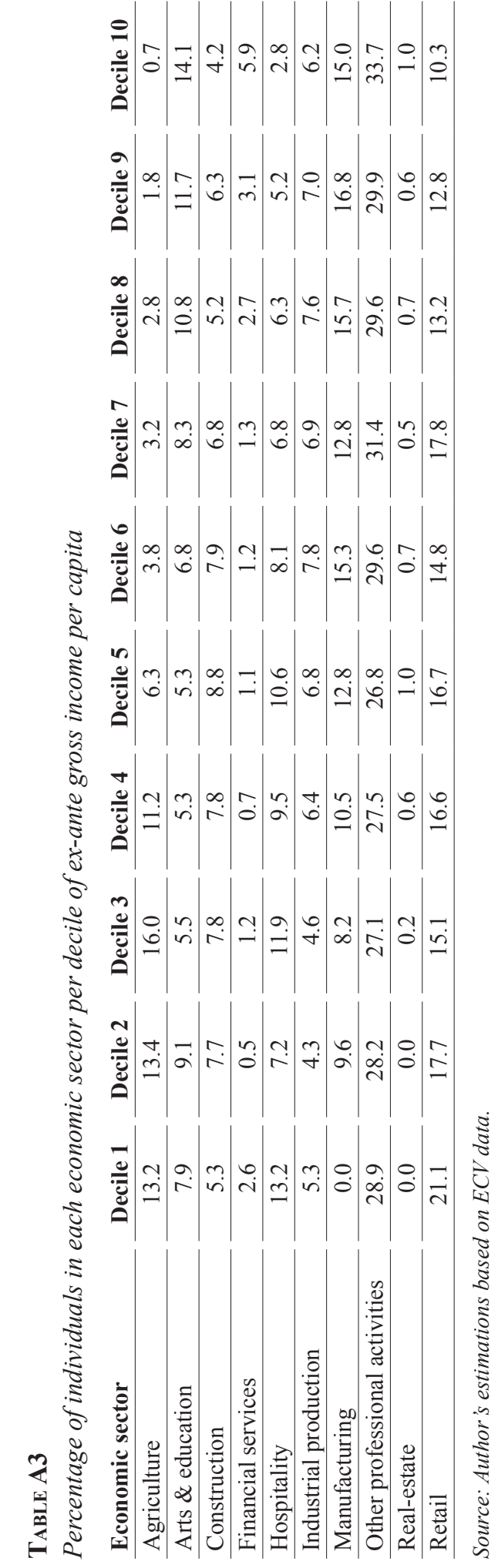

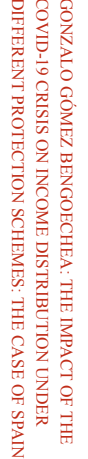




\section{Figure A1}

Gini Index for $10 \%$ and $100 \%$ of households losing from $0 \%$ to $100 \%$ of at-risk income

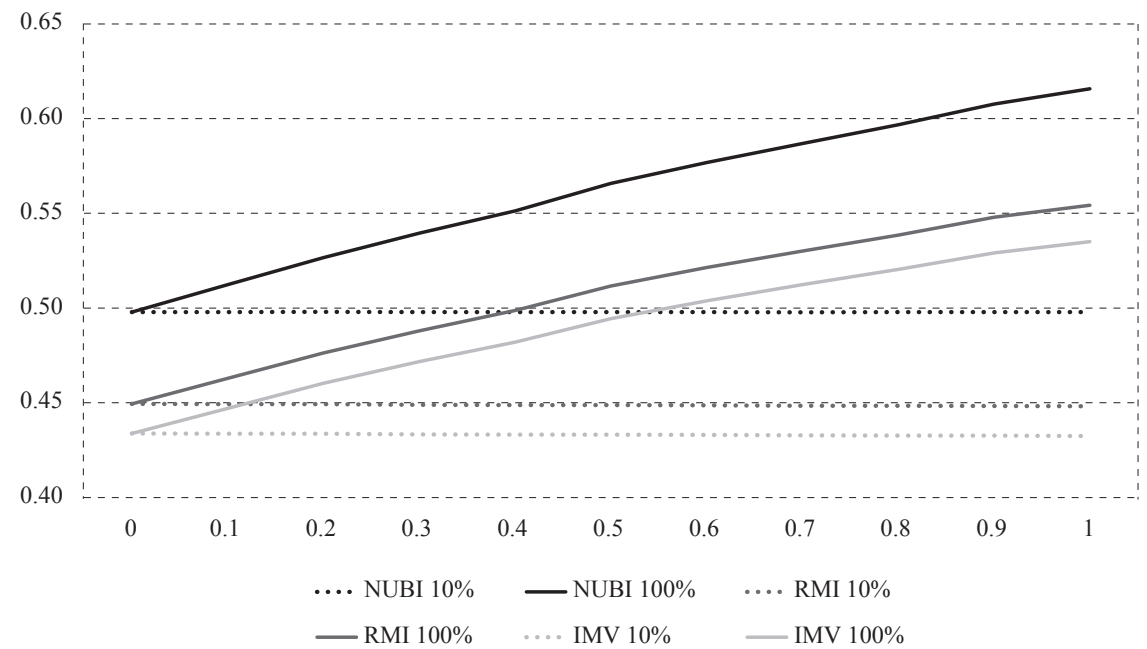

Source: Author's estimations based on ECV data. 